\title{
The Impact of Capital Structure on the Financial Performance of the Jordanian Industrial Companies Listed on the Amman Stock Exchange for the Period 2012-2015
}

\author{
Shireen Mahmoud AlAli \\ Head of Finance and Banking Department \\ Ajloun National University, Jordan
}

Received: July 3, 2017 Accepted: August 2, $2017 \quad$ Published: December 1, 2017

doi:10.5296/ajfa.v9i2.12076 URL: https://doi.org/10.5296/ajfa.v9i2.12076

\begin{abstract}
The purpose of this study was to identify the effect of the capital structure as a percentage of total liabilities to total assets on the financial performance of the Jordanian industrial companies listed on the Amman Stock Exchange for the period 2012-2015.

The study population included all the Jordanian general industrial companies listed on the Amman Stock Exchange. The sample of the study included 10 industrial companies listed on the Amman Stock Exchange. The linear regression analysis was used to test the relationship between variables using the ordinary least squares method (OLS).

The results showed that there is a positive significant impact on the capital structure of the industrial shareholding companies listed in the Amman Stock Exchange as measured by the ratio of equity to total assets, return on equity and return on assets and net earnings per share as an indicator of financial performance.

The results also showed a negative significant impact on the capital structure of industrial shareholding companies listed on the Amman Stock Exchange as measured by total liabilities to total assets, return on equity and return on assets as an indicator of financial performance, and net earnings per share as an indicator of the financial performance indicators.
\end{abstract}

Keywords: Capital Structure, financial performance, Equity, Assets, Earning per share (EPS) 


\section{Introduction}

Financing and investment are two major decision areas in a firm. In the financing decision the manager is concerned with determining the best financing mix or capital structure for his firm. Capital structure decision is the mix of debt and equity that a company uses to finance its business (Damodaran, 2001). The relationship between capital structure decisions and firm value has been extensively investigated in the past few decades. Capital structure could have two effects; according to Desai (2007) firms of the same risk class could possibly have higher cost of capital with higher leverage. Second, capital structure may affect the valuation of the firm, with more leveraged firms, being riskier and consequently valued lower than the less leveraged firms. If the manager of a firm has the shareholders' wealth maximization as his objective, then capital structure is an important decision, for it could lead to an optimal financing mix which maximizes the market price per share of the firm.

Industrial and commercial activities need to be financed, as these activities will not continue unless they have the appropriate funding to enhance the fixed assets and capital requirements of these companies. Capital means the Company's total investments in fixed and current assets. Working capital is the total investment of the Company in current assets that is converted into cash through the Company's normal operations over a period of one year or the operational cycle whichever is longer (Sobh, 2002).

Companies differ in the choice of capital structure due to variety of their use of the available sources of finance as this affects their financial decisions and thus affects their investment decisions. As a result, companies find out the available sources of financing and the characteristics of each one so that they can choose between them to achieve a capital structure that achieves the company's goal, which is to maximize the profitability of the company.

The financing decision is made to determine the appropriate financing structure for the Company's investments, meaning that it is related to the way of financing the total assets of the Company (ie, the left side of the balance sheet, which is the side of liabilities and shareholders' equity, which shows all sources of funding used by the Company) (Almaydani 2004).

After determining the funding elements available to the Company, the Company sets its specific policy regarding the mix of capital structure and the ratio of each component. The cost of each component varies by the degree of risk to which the return of that component is incurred. Therefore, the cost of capital is expected to vary, according to the Company's decision to identify the constituent elements of the capital structure (Alhindi, 1999).

As for the investment decision, it goes to profitable capital investment projects and then determines the appropriate size of the capital budget (Almaydani, 2004).

The performance of the institutions is measured by the ability of the institution to maximize the profit to shareholders and owners, through appropriate financial decisions. These decisions are divided into investment decisions, which consist of investment in fixed and current income generating assets, as well as finance decisions, which are to differentiate 
between sources of internal financing (equity) and short and long-term sources of external financing (loans)(Brindusa, 2012)

\subsection{Factors Influencing The Capital Structure}

There are many factors influencing the Capital Structure the most important that affect the capital structure of the company are the following:

A) Profitability: The expected rate of return of any investment project must be greater than the required rate of return in the capital market so that the economic project can be considered profitable, as the profitability of the company depends on the level of sales and the returns of its investment projects, and this is important in determining the company's borrowing ratio. As the profitability of the company increases, its reliance on borrowing decreases and thus plays a major role in the decision to choose the appropriate capital structure (Hanafi, 2004).

B) Repayment capacity: In the sense that the company is able to pay the loan amount and interest at the maturity date of the loan, by comparing the expected cash flow of the project for the coming years with the loan charge, as the company's ability to pay its financial liabilities affects its good performance and low risk of bankruptcy. (Pouraghajan \& Malekian, 2012 ).

C) Flexibility: Flexibility is defined as the ability of a company's capital structure to cope with changing circumstances, that is, the company is able to transfer from a source of financing to another source with high flexibility without affecting the company's objective and performance. (1995, Pandy).

D) Control: The ability of the Company to impose greater control over elements of the capital structure through its administrative control resulting from the preference of long-term financing owners to borrow instead of issuing new shares so as not to lose part of their control of the company to new shareholders(Siddik, et al., 2016).

Not to mention, the requirements of the capital structure differ from one company to another according to its policy of adapting to these requirements as it sees fit for its objectives and interests (Pandy, 1995).

One of the most important functions of the financial manager is to plan the structure of the company's capital. Accordingly, the finance manager determines the sources of finance for the capital structure in terms of internal finances and external financing and then select the appropriate sources of financing to achieve the objectives of the company. Thus, determining share of funds to be financed by borrowing or ownership, and this can be done through the use of certain methods to determine the appropriate capital structure of the company. The most important of these methods are:

\section{A) Financial and operational leverage method}

The financial and operational leverage is defined by using fixed costs in the company to maximize profits. The upper part of the income statement (I / S) is the business activity of the 
company. The leverage of this part is called the operational leverage, while the lower part of the (I / S) reflects the financial activity of the company and therefore the lever for this part is called financial leverage and reflects the value of debt financed to the capital structure (Gibson, 2007).

The impact of the operational leverage is as follows: Any relative change in sales will result in a greater relative change in operating profit (EBIT: EARNING Before Interest and Tax).Operating leverage is greater in companies where fixed financial costs are high and this leads to increased profits.

The financial leverage effect is as follows: (Any relative change in operating profit will reflect a larger increase in EPS). The effect of the increase in borrowing ratio on the capital structure can be measured by degree of financial leverage, which is defined as the change in the ratio of earnings per share to the percentage of change in operating profit. (Gibson, 2007).

\subsection{Degree of Financial Leverage $(D F L=E B I T / E B T)$}

This means that if the EPS ratio changes more than the change in the ratio of operating profit, the leverage degree is greater than the correct one $>1$. This indicates the higher financial risk resulting from the larger use of borrowing funds. Otherwise, if the earnings per share changes less than The change in operating profit then the DFL is less than the correct one $<1$. This means that the financial risk is reduced because the company tends to use the financing of the property more than the financing by borrowing. If the capital structure does not include loans or there are no fixed financial obligations on the company, the DFL is equal to the right one $=1$, which means that there is no financial risk for the company and it is because of using property financing only (Goyal, 2013).

\section{B) Debt ratio analysis}

Using debt ratio, the capital structure can be determined by long-term financing sources, because this type of ratio gives an accurate indication of the financial position of the enterprise in the long term.

This ratio shows the extent to which the Company is able to meet the fixed obligations and also shows the amount of the debt contribution to capital (Khan and Ghraibeh, 1995). One of the advantages of using debt in financing the company is to increase the company's profits by reducing the value of the company's income tax (Tax Shield). A disadvantage of using debt is that it represents the cost of the loan represented by the financial obligations and the service of those obligations of interest.

\section{Problem Statement}

The choice between finance based on short and long-term bank and commercial debt and bonds, or reliance on equity represented by ordinary shares, compulsory and voluntary reserves and undistributed profits, is one of the important financial decisions facing the financial management of industrial joint stock companies (Ogebe, et al. 2013). The relationship between the capital structure and the value of the enterprise Has attracted the attention of researchers, academics and the management of facilities and employees. The 
study examined the relationship between the capital structure as measured by the ratio of liabilities to assets and equity to the assets of Jordanian industrial companies listed on the Amman Stock Exchange on the performance of these companies measured by return on assets, return on equity and share of net profits in order to reach To the results and recommendations that will enhance the performance of Jordanian industrial joint stock companies.

The problem of the study is to answer the following main question: Does the capital structure affect the financial performance of Jordanian industrial joint-stock companies?

\section{Literature Review}

Several studies have been conducted to examine the impact of capital structure on performance.

Using panel data of 22 banks for the period of2005-2014 (Siddik, et al., 2016) explain that Capital structure decision plays an imperative role in firm's performance. Recognizing the importance, there has been many studies inspected the rapport of capital structure with performance of firms and findings of those studies are inconclusive. In addition, there is relative deficiency of empirical studies examining the link of capital structure with performance of banks in Bangladesh. Results from pooled ordinary least square analysis show that there are inverse impacts of capital structure on bank's performance.

To investigate empirically the impact of capital structure on firm performance, (Abeywardhana, 2015) conduct a study examined the impact of capital structure on firm performance of manufacturing sector SMEs in UK for the period of 1998-2008. Results of this study reveals that there is a significant negative relationship between leverage and firm performance (ROA, ROCE), strong negative relationship between liquidity and firm performance and highly significant positive relationship between size and the firm performance. This study concluded that firms which perform well do not rely on debt capital and they finance their operations from retained earnings and specially SMEs have less access to external finance and face difficulties in borrowing funds.

The study of (Mwangi, et al., 2014) investigated the relationship between capital structure on the performance of non-financial companies listed in the Nairobi Securities Exchange, Kenya. The study employed an explanatory non- experimental research design. A census of 42 non-financial companies listed in the Nairobi Securities Exchange, Kenya was taken. The study used secondary panel data contained in the annual reports and financial statements of listed non-financial companies. The results revealed that financial leverage had a statistically significant negative association with performance as measured by return on assets (ROA) and return on equity (ROE).

The research conduct by (Akeem, et al., 2014) examines the effect of capital structure on firm's performance with a case study of manufacturing companies in Nigeria from 2003 to 2012 with the purpose of providing a critical appraisal of the need and importance of capital structure. This research observes that capital structure measures (total debt and debt to equity ratio) are negatively related to firm performance. It is hereby recommended that firms should 
use more of equity than debt in financing their business activities, in as much as the value of a business can be enhanced using debt capital. Hence firms should establish the point at which the weighted average cost of capital is minimal and maintain that gearing ratio so that the company's value will not be eroded, as the firm's capital structure is optimal at this point ceteris paribus.

the paper of (Goyal, 2013) seeks to study the impact of capital structure on profitability of public sector banks in India listed on national stock exchange during 2008 to 2012 methodology-Regression Analysis has been used for establishing relationship between Return on Equity, Return on Assets \& EPS with capital structure Results. The findings reveal positive relationship of short term debt with profitability as measured by ROE, ROA \& EPS.

The (Alhamdan \& Alqudah 2013) study aims to test the effect of the capital structure on the performance of the Jordanian banks listed on the Amman Stock Exchange (13 banks) for the period 1991-2010. The study used the analysis of table data (Panel Data) using the fixed and random effects models and the general lower squares method (GLS) to test the hypotheses of the study. The results of the study showed that the capital structure measured by the ratio of liabilities to assets has a positive and statistically significant effect on the performance of Jordanian banks measured by return on assets, return on equity, and share of net profits. As for the ratio of equity to assets, the results showed a positive and statistically significant impact on the return on assets and a negative and statistically significant impact on share per net profits and return on equity, while the size of the bank had a positive and statistically significant impact on Performance of Jordanian Banks.

Ebrati et al. (2013) try to examined the impact of the capital structure measured by (liabilities to assets and liabilities to equity) on the financial performance of (85) companies listed on the Tehran market using the multiple regression in the period 2006-2011.

The study found that the capital structure has a positive and statistically significant effect on the financial performance measured by the return on equity, while it has a negative and statistically significant impact on the return on assets and the share of net profits.

(Saeed, et al., 2013)The study examined the impact of the capital structure on the performance of Pakistani banks for the period 2007-2011 using the data of the banks listed on the Karachi Stock Exchange, and models of multiple regression were applied to estimate the relationship between capital structure and banking performance. Performance was measured by return on assets, return on equity and return on earnings per share. Capital structure determinants include long-term debt to capital, short-term debt to capital and ratio of total debt to capital.

The study found a positive relationship between the determinants of the capital structure and the performance of the banking industry.

\section{Methodology}

The study population includes all the Jordanian general industrial shareholding companies listed on the Amman Stock Exchange. The sample of the study includes (10) industrial 


\section{Al Macrothink}

Asian Journal of Finance \& Accounting

ISSN 1946-052X

2017, Vol. 9, No. 2

companies listed on the Amman Financial Market, which meet the following conditions to ensure measurement of the study variables:

1) The capital of the company exceeds (15) million JD.

2) To be listed in the market for more than (15) years ago.

3) They have not been incorporated during the study period.

4) Not to be suspended from trading.

5) The necessary financial data on the companies during the study period to measure the variables of the study.

The following table shows, sample study companies:

Table 1. Sample study companies

\begin{tabular}{|l|l|c|c|c|c|}
\hline \multirow{2}{*}{ No } & \multirow{2}{*}{ Company name } & \multicolumn{3}{c|}{ Authorized Capital (million JD ) } \\
\cline { 3 - 6 } & & $\mathbf{2 0 1 2}$ & $\mathbf{2 0 1 3}$ & $\mathbf{2 0 1 4}$ & $\mathbf{2 0 1 5}$ \\
\hline 1 & The Jordanian Pharmaceutical Manufacturing & 20 & 20 & 20 & 20 \\
\hline 2 & Jordan Poultry Processing \& Marketing & 15 & 17 & 23 & 23 \\
\hline 3 & Ready Mix Concrete And Construction Supplies & 25 & 25 & 25 & 25 \\
\hline 4 & Middle East Specialized Cables Company & 39 & 39 & 39 & 39 \\
\hline 5 & Arab Electrical Industries & 16 & 16 & 16 & 16 \\
\hline 6 & National Poultry & 30 & 30 & 30 & 30 \\
\hline 7 & Dar Al Dawa Development \& Investment & 23 & 25 & 25 & 25 \\
\hline 8 & The Jordan Cement Factories & 60.5 & 60.5 & 60.5 & 60.5 \\
\hline 9 & United Cable Industries & 40 & 40 & 40 & 40 \\
\hline 10 & Jordan Phosphate Mines & 75 & 75 & 75 & 75 \\
\hline
\end{tabular}

\subsection{Data collection sources}

The study data were collected from the following sources:

1) Directory of public shareholding companies for the years that cover the study period.

2) Published annual financial reports for public shareholding companies in the Jordanian industry, which constitute the study sample for the period 2012-2015.

\subsection{Study Model}

To achieve the study objective, the following model has been used: 


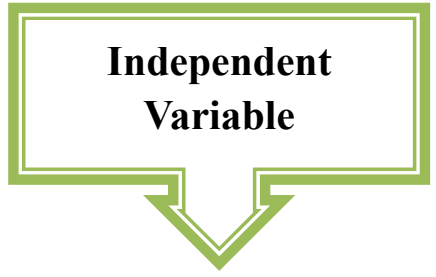

\section{Capital Structure}

- Total Liabilities to Total Assets.

- Equity to Total Assets.

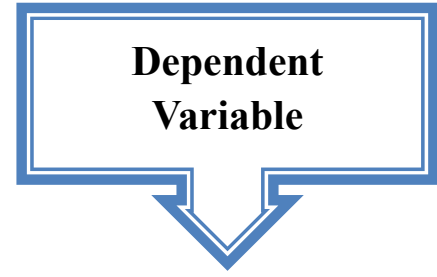

Financial

Performance

- Return On Equity

(ROE)

- Return on assets

(ROA)

(Study Model)

The impact of the capital structure on the financial performance of companies was measured using the linear regression model, which is the following equation:

$$
\mathrm{Y}=\alpha+\beta \mathrm{X}
$$

Where $(\mathrm{X})$ is the independent variables which is the capital structure and $(\mathrm{Y})$ is the dependent variable, which is the company's financial performance (profitability ratios).

\section{Independent variables}

The independent variables are the Capital Structure Ratios. These ratios are used as a tool to assess the ability of companies to meet their long-term liabilities. The following metrics for capital structure ratios will be used in this study:

1- Total Liability to Total Assets Ratio (LAR).

2- Equity to Total Assets Ratio (EAR)

\section{The dependent variable}

The dependent variable is the company's financial performance (profitability ratios). These percentages are as follows:

1- Return on Equity (ROE).

2- Return on Assets (ROA) 
3- Earnings Per Share (EPS)

\section{Hypotheses of the Study}

To achieve the objectives of the study and to reach results that can be utilized, the following hypotheses are designed

The main hypothesis: (There is a statistically significant impact at the level $(\alpha \leq 0.05)$ of the capital structure on financial performance of Jordanian industrial companies listed on the Amman Stock Exchange.

The following sub-assumptions are derived from this hypothesis:

- There is a statistically significant impact at the level $(\alpha \leq 0.05)$ of the capital structure as measured by (total liabilities to total assets and equity ratio) and the financial performance of Jordanian industrial companies listed on the Amman Stock Exchange as measured by Return OnEquity (ROE).

- $\quad$ There is a statistically impact at the level $(\alpha \leq 0.05)$ of the capital structure as measured by (total liabilities to total assets and equity ratio) and the financial performance of Jordanian industrial companies listed on the Amman Stock Exchange as measured by Return On Assets (ROA).

- There is a statistically impact at the level $(\alpha \leq 0.05)$ of the capital structure as measured by (total liabilities to total assets and equity ratio) and the financial performance of Jordanian industrial companies listed on the Amman Stock Exchange as measured by Earning Per Share (EPS).

The linear regression equation thus becomes as follows:

$$
\begin{aligned}
& \mathrm{ROE}=\alpha+\beta 1(\mathrm{LAR})+\beta 2(\mathrm{EAR}) \\
& \mathrm{ROA}=\alpha+(\mathrm{LAR})+\beta 2(\mathrm{EAR}) \\
& \mathrm{EP}=\alpha+(\mathrm{LAR})+\beta 2(\mathrm{EAR})
\end{aligned}
$$

\section{Methods of data analysis}

The linear regression analysis was used to test the relationship between independent and dependent variables. The regression equation described in the study model was estimated using the OLS method, which results in a regression line where the sum of the square deviations from the line of points observed, is minimal. 


\section{Analysis of results and hypothesis testing}

\subsection{Descriptive analysis of study data}

Based on aggregated data of ten Jordanian shareholding companies listed on the Amman Stock Exchange for the period (2012-2015), the following table shows the data of these companies, which will be used in the model and test hypotheses.

Table 2. Cumulative financial dataof industrial companies Sample of study $(n=10)$

\begin{tabular}{|l|c|c|c|c|}
\hline & $\mathbf{2 0 1 2}$ & $\mathbf{2 0 1 3}$ & $\mathbf{2 0 1 4}$ & $\mathbf{2 0 1 5}$ \\
\hline \multicolumn{5}{|c|}{ Data of independent variables } \\
\hline Total Assets (TA) & $1,867,200,595$ & $1,781,414,637$ & $1,660,045,853$ & $1,614,928,066$ \\
\hline Total Liabilities(TL) & $754,770,686$ & $688,201,257$ & $528,689,125$ & $549,719,345$ \\
\hline Equity(E) & $1,090,452,546$ & $1,071,991,993$ & $1,110,246,651$ & $1,046,854,876$ \\
\hline $\begin{array}{l}\text { Total Liabilities to } \\
\text { Total Assets (LAR). }\end{array}$ & 0.40 & 0.39 & 0.32 & 0.34 \\
\hline $\begin{array}{l}\text { Equity to Total } \\
\text { Assets(EAR) }\end{array}$ & 0.69 & 0.64 & 0.48 & 0.53 \\
\hline $\begin{array}{l}\text { Return On Equity } \\
\text { (ROE)\% }\end{array}$ & 62 & 76 & 811 & $(207)$ \\
\hline $\begin{array}{l}\text { Return on assets } \\
\text { (ROA)\% }\end{array}$ & 17 & 9 & 6 & 2 \\
\hline $\begin{array}{l}\text { Earnings Per Share } \\
\text { (EPS)\% }\end{array}$ & 0.43 & -0.12 & 1.16 & 2.45 \\
\hline
\end{tabular}

\subsection{The suitability of the regression model test}

To determine the suitability of the regression model in the analysis of the study data and to reach real results, the following tests were carried out:

\subsubsection{The unit root test for time series stability}

This test aims to examine the dormancy of time series, in order to avoid the problem of false regression resulting from the non-dormancy of the time series, and the most important tests of the root of the unit, the first step in the analysis of the data of the study is to test the dormancy of these time series through the unit root test. The most important test used to test unit root: (Augmented Dickey-Fuller test, Phillips Peron test).

\section{A. Augmented Dickey - Fuller, 1981:}

The Dickey-Fuller test is one of the most popular tests in practical application. This test is used to verify the dormancy of the time series. The ADF test is based on the nihilistic hypothesis, which states that the presence of the root of the unit leads to the non-dormancy of the time series (Bhunia and Das, 2012). Table (2) shows the results of the augmented/Dicky Fuller test for the study data. 


\section{1) Macrothink}

Table 3. Augmented Dickey - Fuller test

\begin{tabular}{|l|c|c|c|}
\hline \multicolumn{1}{|c|}{ Variable } & $(\mathbf{t})$ value & (t) tabled value & sig \\
\hline Total Liabilities to Total Assets (LAR). & $1.694-$ & $2.945-$ & 0.427 \\
\hline Equity to Total Assets (EAR) & $1.676-$ & $2.945-$ & 0.433 \\
\hline Return On Equity (ROE)\% & 1.141 & $2.945-$ & 0.997 \\
\hline Return on assets (ROA)\% $\%$ - $\%$ - & $0.942-$ & $2.945-$ & 0.761 \\
\hline Earnings Per Share (EPS)\% & $0.651-$ & $2.945-$ & 0.845 \\
\hline \multicolumn{2}{|c|}{ At first difference } \\
\hline Total Liabilities to Total Assets (LAR). & $5.970-$ & $2.957-$ & 0.000 \\
\hline Equity to Total Assets (EAR) & $4.646-$ & $2.957-$ & 0.000 \\
\hline Return On Equity (ROE)\% & $4.549-$ & $2.957-$ & 0.001 \\
\hline Return on assets (ROA)\% & $5.149-$ & $2.957-$ & 0.000 \\
\hline Earnings Per Share (EPS)\% & $4.574-$ & $2.957-$ & 0.000 \\
\hline
\end{tabular}

The data of the previous table indicate that all the variables of the study are not dormant at the time of the augmented Dicky-Fuller test application, since the absolute values of the calculated $(\mathrm{t})$ are lower than the absolute values of the tabular (critical) ( $\mathrm{t}$ ) of all variables. This indicates -according to this test- that there is unit root. After consideration of the first difference, all variables seemed dormant at a significant level (0.05). The absolute values of calculated $(\mathrm{t})$ are greater than the absolute values of tabular (critical) $(\mathrm{t})$ for all variables.

\section{B. Phillips-Perron, 1988:}

The Phillips-Byron test aims to verify the dormancy of the time series by testing the hypothesis of the root of the unit in the time series. What distinguishes the Phillips and Byron test is that it does not solve the problem of serial correlation of errors in the same way as the augmented Dicky-Fuller test (Fahami et al., 2014). The null hypothesis is usually rejected for the existence of the unit root, i.e., the non-dormancy of the series if the calculated absolute values of the test are greater than the critical absolute values. Table (4-3) shows the results of the Phillips and Perron test for the study data. 
Table 4. Phillips-Perron test

\begin{tabular}{|c|c|c|c|}
\hline Variable & (t) value & (t) tabled value & sig \\
\hline$(\mathrm{LAR})$ & $1.71-$ & $2.954-$ & 0.412 \\
\hline$(\mathrm{EAR})$ & $1.67-$ & $2.954-$ & 0.433 \\
\hline$\%(\mathrm{ROE})$ & 1.912 & $2.954-$ & 0.999 \\
\hline$\%(\mathrm{ROA})$ & $1.169-$ & $2.954-$ & 0.675 \\
\hline$\%(\mathrm{ER})$ & $0.736-$ & $2.954-$ & 0.823 \\
\hline \multicolumn{4}{|c|}{ At first difference } \\
\hline (LAR) & $5.970-$ & $2.957-$ & 0.000 \\
\hline (EAR) & $7.175-$ & $2.957-$ & 0.000 \\
\hline$\%(\mathrm{ROE})$ & $4.549-$ & $2.957-$ & 0.001 \\
\hline$\%(\mathrm{ROA})$ & $5.149-$ & $2.957-$ & 0.000 \\
\hline$\%(\mathrm{ER})$ & $4.484-$ & $2.957-$ & 0.001 \\
\hline
\end{tabular}

The results of the Phillips-Perron test (PP) indicate that all the study variables are non-dormant at the time of this test; the absolute values of calculated ( $\mathrm{t}$ ) are lower than the absolute values of tabular (critical) $(\mathrm{t})$ for all variables. That indicates the existence of the root of the unit according to this test. After taking the first difference, all the variables were marked dormant at a significant level (0.05), where the absolute values of calculated $(t)$ are greater than the absolute values of tabular (critical) (t) for all variables.

The results shown in Tables 2 and 3 clearly indicate the stability and dormancy of the time series of the study data. This means that the results obtained from the Linear and Multigraph regression test will be real and will not be false.

\subsubsection{The Unit Root Test}

Table (4) shows the results of the Unit Root test between independent study variables.

Table 5. Unit Root Test

\begin{tabular}{|c|c|c|}
\hline Lags & Q - stat & Prob \\
\hline$(\mathrm{LAR})$ & 0.711 & 0.422 \\
\hline$(\mathrm{EAR})$ & 1.047 & 0.354 \\
\hline$\%(\mathrm{ROE})$ & 1.462 & 0.723 \\
\hline$\%(\mathrm{ROA})$ & 1.465 & 0.922 \\
\hline$\%(\mathrm{ER})$ & 1.465 & 0.687 \\
\hline
\end{tabular}

The above table shows that the probability value of all study variables was greater than $(0.05)$. This indicates that there is no problem of self-correlation among study variables. 


\subsection{Testing hypotheses}

After confirming the dormancy and stability of the time series of the study data, and the absence of the problem of self-correlation between the variables of the study, the hypotheses of the study will be tested based on the multiple regression model, as follows:

\subsubsection{First: Testing the first sub-hypothesis}

This hypothesis states that (There is a statistically significant impact at the level $(\alpha \leq 0.05)$ of the capital structure as measured by (total liabilities to total assets and equity ratio) and the financial performance of Jordanian industrial companies listed on the Amman Stock Exchange as measured by return on equity (ROE).

Table 6. Regression test (The impact of capital structure on return on equity)

\begin{tabular}{|c|c|c|c|c|c|c|c|c|}
\hline $\begin{array}{c}\text { Dependent } \\
\text { variable }\end{array}$ & $\begin{array}{c}\text { Constant } \\
(\boldsymbol{\alpha})\end{array}$ & $\mathbf{R}^{2}$ & $\begin{array}{c}\text { (f) } \\
\text { value }\end{array}$ & Sig. level & $\begin{array}{c}\text { Independent } \\
\text { variable }\end{array}$ & $(\beta)$ & (t) value & (t) Sig \\
\hline $\begin{array}{c}\text { return on } \\
\text { equity } \\
\text { (ROE) }\end{array}$ & 0.32 & 0.965 & 204.37 & 0.000 & $\begin{array}{c}\text { total liabilities } \\
\text { to total assets }\end{array}$ & -0.0877 & $0.074-$ & 0.941 \\
\cline { 5 - 9 } & & & equity ratio & 0.7370 & 6.511 & 0.000 \\
\hline
\end{tabular}

* The effect is statistically significant at $(\alpha \leq 0.05)$

From the previous table, the regression equation for the effect of (gross liabilities to total assets, equity ratio) on ROE can be calculated as follows:

$$
\mathrm{Y}=\alpha+\beta_{1} \mathrm{X}_{1}+\beta_{2} \mathrm{X}_{2}
$$

Whereas:

$\mathrm{Y}=$ return on equity.

$\alpha=$ Equation constant ( $\mathrm{Y}$ value when total liabilities to total assets, equity ratio is constant).

$\beta_{1}=$ coefficient, the amount of change in the return on equity if the total liability to the total assets changes in a single unit.

$\beta_{2}=$ coefficient, the amount of change in the return on equity if the equity ratio changes in one unit.

$\mathrm{X} 1=$ Total liabilities to total assets.

$\mathrm{X} 2$ = Equity Ratio.

Thus, the equation is as follows:7

Return on equity $=0.32-0.0877$ (Total liabilities to total assets) +0.737 (Equity ratio)

Thus, the effect of total liabilities to total assets on return on equity is negative, and the equity ratio on return on equity is positive. 


\section{Macrothink}

The results of Table (6) indicate that the value of $\left(\mathrm{r}^{2}\right)=(0.965)$. This means that the variance in (total liabilities to total assets, equity ratio) has explained $(96.5 \%)$ of variance in return on equity, and (3.5\%) due to other factors not covered in the study. The value of (F) was (204.37) at a significant level (0.000), which confirms the significance of the regression model at a significant level $(\alpha \leq 0.05)$.

\subsubsection{Second: Testing the second sub-hypothesis}

The hypothesis assumes that (There is a statistically impact at the level $(\alpha \leq 0.05)$ of the capital structure as measured by (total liabilities to total assets and equity ratio) and the financial performance of Jordanian industrial companies listed on the Amman Stock Exchange as measured by return on assets (ROA).

Table 7. Regression test (The impact of capital structure on return on assets)

\begin{tabular}{|c|c|c|c|c|c|c|c|c|}
\hline $\begin{array}{c}\text { Dependent } \\
\text { variable }\end{array}$ & $\begin{array}{c}\text { Constant } \\
(\boldsymbol{\alpha})\end{array}$ & $\mathbf{R}^{\mathbf{2}}$ & $\begin{array}{c}(\mathbf{f}) \\
\text { value }\end{array}$ & $\begin{array}{l}\text { Sig. } \\
\text { level }\end{array}$ & $\begin{array}{c}\text { Independent } \\
\text { variable }\end{array}$ & $\mathbf{( \beta )}$ & $\begin{array}{c}(\mathbf{t}) \\
\text { value }\end{array}$ & (t) Sig \\
\hline $\begin{array}{c}\text { return on } \\
\text { assets } \\
(\mathrm{ROA})\end{array}$ & 0.86 & 0.842 & 122.6 & 0.000 & $\begin{array}{c}\text { total liabilities } \\
\text { to total assets }\end{array}$ & -0.024 & 42.55 & 0.000 \\
\cline { 5 - 9 } & & & & equity ratio & 0.66 & 6.511 & 0.000 \\
\hline
\end{tabular}

* The effect is statistically significant at $(\alpha \leq 0.05)$

From the previous table, the regression equation for the effect of (gross liabilities to total assets, equity ratio) on return on assets can be calculated as follows:

$$
\mathrm{Y}=\alpha+\beta_{1} \mathrm{X}_{1}+\beta_{2} \mathrm{X}_{2}
$$

Whereas:

$\mathrm{Y}=$ Return on Assets.

$\alpha=$ Equation constant (Y value when total liabilities to total assets, equity ratio is constant).

$\beta_{1}=$ coefficient, the amount of change in the return on assets if total liabilities to total assetschange in one unit.

$\beta_{2}=$ coefficient, the amount of change in the return on assets if the equity ratio changes by one unit.

$\mathrm{X}_{1}=$ Total liabilities to total assets.

$\mathrm{X}_{2}=$ Equity Ratio.

Thus, the equation is as follows:

Return on Assets $=0.86-0.024$ (Total Liabilities to Total Assets $)+0.66$ (Equity Ratio)

Thus, the effect of total liabilities to total assets on return on assets has had a negative impact, and the equity ratio on return on assets has had a positive effect. 


\section{Macrothink Institute ${ }^{\text {TM }}$}

The results of Table (7) indicate that the value of the coefficient of determination reached ( $\mathrm{r} 2$ $=0.842$ ). This means that the difference in (total liabilities to total assets, equity ratio) has been explained by $84.2 \%$ of the variance in return on assets and $15.8 \%$ due to other factors not covered by the study. The value of (F) was (122.6) at a significant level (0.000), which confirms the significance of the regression model at a significant level $(\alpha \leq 0.05)$.

\subsubsection{Third: Testing the third hypothesis}

The hypothesis states that (There is a statistically impact at the level $(\alpha \leq 0.05)$ of the capital structure as measured by (total liabilities to total assets and equity ratio) and the financial performance of Jordanian industrial companies listed on the Amman Stock Exchange as measured by earning per share (EPS).

Table 8. Regression test (The impact of capital structure on earning per share)

\begin{tabular}{|c|c|c|c|c|c|c|c|c|}
\hline $\begin{array}{c}\text { Dependent } \\
\text { variable }\end{array}$ & $\begin{array}{c}\text { Constant } \\
(\boldsymbol{\alpha})\end{array}$ & $\mathbf{R}^{\mathbf{2}}$ & $\begin{array}{c}(\mathbf{f}) \\
\text { value }\end{array}$ & Sig. level & $\begin{array}{c}\text { Independent } \\
\text { variable }\end{array}$ & $\mathbf{( \beta )}$ & $\begin{array}{c}(\mathbf{t}) \\
\text { value }\end{array}$ & $\mathbf{( t ) \text { Sig }}$ \\
\hline $\begin{array}{c}\text { earnings } \\
\text { per share } \\
(\mathrm{EPS})\end{array}$ & 0.58 & 0.893 & 205.05 & 0.000 & $\begin{array}{c}\text { total liabilities } \\
\text { to total assets }\end{array}$ & -0.102 & 38.55 & 0.000 \\
\cline { 5 - 9 } & & & & equity ratio & 0.74 & 12.221 & 0.000 \\
\hline
\end{tabular}

* The effect is statistically significant at $(\mathrm{P} \leq 0.05)$

From the previous table, the regression equation for the effect of (total liabilities to total assets, equity ratio) on net profit per share can be calculated as follows:

$$
\mathrm{Y}=\alpha+\beta_{1} \mathrm{X}_{1}+\beta_{2} \mathrm{X}_{2}
$$

Whereas:

$\mathrm{Y}=$ Net profit per share.

$\alpha=$ Equation constant (Y value when total liabilities to total assets, equity ratio is constant).

$\beta_{1}=$ Conjugate, the amount of change per share of net profit if total liabilities to total assets change in one unit.

$\beta_{2}=$ Conjugate, which is the amount of change per share of net profit if the equity ratio changes in one unit.

$\mathrm{X}_{1}=$ Total liabilities to total assets.

$\mathrm{X}_{2}=$ Equity Ratio.

Thus, the equation is as follows:

Net profit per share $=0.58-0.102$ (Total liabilities to total assets) +0.74 (Equity ratio)

Thus, the effect of total liabilities to total assets on net profit per share is negative, and the effect of equity ratio on net profit per share has had a positive effect. 


\section{$\Lambda$ Macrothink}

The results of Table (4-7) indicate that the value of $\left(r^{2}\right)=(0.893)$. This means that the difference in (total liabilities to total assets, equity ratio) has explained $(89.3 \%$ of variance in net profits per share, and $10.7 \%$ of the net profit due to other factors not covered in the study. The value of $(\mathrm{F})$ was $(205.05)$ at a significant level (prob $=0.000)$, which confirms the significance of the regression model at the level of significance $(\alpha \leq 0.05)$.

The results obtained in tables (4-5), (4-6) and (4-7) show that there is a statistically significant effect on the capital structure (as measured by total liabilities to total assets, equity ratio) on each one of the following: Return On Equity (ROE), Return On Assets (ROA) and Earnings Per Share (EPS).

\section{Conclusions}

The study concluded that there is a statistically significant positive effect of capital structure in the industrial shareholding companies listed in the Amman Stock Exchange as measured by the ratio of equity to total assets, on return on equity (ROE), return on assets (ROA), and earning per share(EPS) as an indicator of financial performance.

The study also concluded that there is a statistically significant positive effect of capital structure in the industrial shareholding companies listed in the Amman Stock Exchange as measured by the ratio of equity to total assets, on return on equity (ROE), return on assets(ROA) and earning per share (EPR), as an indicator of financial performance.

\section{Recommendations}

After discussing the results of the statistical analysis of this study on the impact of the capital structure on the financial performance of Jordanian industrial joint stock companies, the researcher recommends the following:

1- Disclose more and more accurately about the financial and accounting information of Jordanian industrial joint stock companies listed on the Amman Stock Exchange.

2- Lenders can use the results of this study as factors in estimating the expected volume of demand on their money. Lenders can predict the financial performance of a company by estimating its need for funds to fund its various activities.

3- Jordanian industrial joint stock companies should take into consideration when deciding to increase their debt or reduce it and its effect on the financial performance of the company.

4- The Jordanian industrial joint stock companies should develop new strategies to increase the efficiency of the financial performance of the company, such as the use of efficient management.

5- Jordanian industrial joint stock companies should use modern technological tools and means, thus reducing the value of costs and thus increasing the value of profits as an indicator of the efficiency of financial performance. 


\section{References}

Abeywardhana, K. (2015). Impact of Capital Structure on Firm Performance: Evidence from Manufacturing Sector SMEs in UK. International Journal of Business and Management Invention, 3(12), 1-12.

Al-Hamdan, N., \& Al-Qudah, A. (2013). The Effect of the Capital Structure on the Performance of Jordanian Banks listed on the Amman Stock Exchange: An Analytical Study. Al-Manara Journal, 19(4), 159-185.

Al-Hindi, M. (1999). Financial Management: A Contemporary Analytical Approach. Fourth Edition, Modern Arab Office, Alexandria.

Al-Maydani, M. (2004). Corporate Finance Management. Al-Kaibaan Library, Olaya-Riyadh, Saudi Arabia.

Brindusa, M. (2012). Capital Structure and Firm Performance. Economy Transdisciplinarity Cognition, 15(1), 76-82.

Damodaran,F. (2001). Corporate Finance. Theory and Practice (2nd edition). New York:Wiely

Desai, A. (2007). Corporate Tax Avoidance and Firm Value. Harvard University and NBER

Ebrati, M. R., Emadi, F., Balasang, R. S., \& Safari. (2013). The impact of capital structure on firm performance: Evidence from Tehran stock exchange. Australian Journal of Basic and Applied Sciences, 7(4), 1-8.

Gibson, H., \& Charles A. (2007). Financial Reporting \&Analysis. 10 ${ }^{\text {th }}$ edition Thomson South - Western, 321-323.

Goyal, A. (2013). Impact of Capital Structure on Performance of Listed Public Sector Banks in India. International Journal of Business and Management Invention, 2(10), 35-43.

Hanafi, A.G. (2004). Fundamentals of Finance and Financial Management. University House, Faculty of Commerce, Alexandria University, Alexandria.

Khan, M., \& Ghraibeh, H. (1995). Financial management. John, Elie and Sons, Jordan Book Center.

Mwangi, L., Makau, S., \& Kosimbei, G. (2014). Relationship between Capital Structure and Performance of Non-Financial Companies Listed In the Nairobi Securities Exchange, Kenya. Global Journal of Contemporary Research in Accounting, Auditing and Business Ethics, 1(2), $72-90$.

Ogebe, P., Ogebe, J., \& Alewi, K. (2013). The Impact of Capital Structure on Firms' Performance in Nigeria. Augustine College of Education, Nigeria.

Pandy, IM. (1995). Financial Management. $7^{\text {th }}$ edition.vikas Publishing House. New Dellhi. 


\section{Macrothink}

Asian Journal of Finance \& Accounting ISSN 1946-052X 2017, Vol. 9, No. 2

Pouraghajan, A., \& Malekian, E. (2012). The Relationship between Capital Structure and Firm Performance Evaluation Measures: Evidence from the Tehran Stock Exchange. International Journal of Business and Commerce, 1(9), 166-181.

Saeed, M, M., Gull, A, A., \& Rasheed, M, Y. (2013). Impact of capital structure on banking performance (a case study of Pakistan). Interdisciplinary Journal of Contemporary Research in Business Copyright. Institute of Interdisciplinary Business Research, 4(10), 220-240.

Siddik, N., Kabiraj, S., \& Joghee, S. (2016). Impacts of Capital Structure on Performance of Banks in a Developing Economy: Evidence from Bangladesh. Journal of Financial Studies, 5(13), 1-13. https://doi.org/10.20944/preprints201611.0110.v1

Sobh, M. (2002). Working Capital and Project Finance. Al-Bayan for Printing and Publishing, Second Edition. 